\title{
Correção da Falha Óssea Femoral e Tibial pelo Método do Transporte Osseo de llizarov
}

\author{
Femoral and Tibial Bone Loss Correction Using llizarov's Bone Transport
}

Celso Herminio Ferraz PICado ${ }^{1}$; Clebber Antonio Jansen Paccola² E Eugenio Freire Andrade Fillio 3

\section{RESUMO}

Analisamos retrospectivamente 11 pacientes submetidos à técnica do transporte ósseo de llizarov, todos portadores de falha óssea diafisária secundária a ressecção de segmentos ósseos infectados, 5 localizadas no fêmur e 6 na tíbia. No grupo de pacientes com lesão femoral a falha óssea variou de $7 \mathrm{~cm}$ a $12 \mathrm{~cm}$, em dois destes pacientes havia encurtamento do membro de $2 \mathrm{~cm}$. No grupo com lesão tibial a falha óssea variou de $2,5 \mathrm{~cm}$ a $10 \mathrm{~cm}$, com encurtamento do membro em dois pacientes de $1,5 \mathrm{~cm}$ e $2 \mathrm{~cm}$ respectivamente. O tempo médio de seguimento desde o final do tratamento até essa avaliação foi de 49 mêses para os pacientes portadores de lesão femoral e de 28,3 meses para os pacientes portadores de lesão tibial. O transporte femoral foi do tipo bifocal, o transporte tibial foi bifocal em 4 pacientes e trifocal em 2 pacientes. Em todos nossos pacientes ocorreu formação do regenerado. A consolidação do foco alvo foi naturalmente obtida em 7 pacientes, um paciente necessitou enxertia óssea para obtenção da consolidação deste foco. Em 3 pacientes a não união do foco alvo fez com que fosse modificado o método de tratamento, com a retirada do fixador circular externo. Em todos os pacientes ocorreu infecção no trajeto dos fios. Houve quebra dos fios de toda montagem feita na coxa. Todos fios perderam a tensão que inicialmente Ihes foram imposta. Dois pacientes submetidos ao transporte femoral evoluíram com artrite séptica do joelho. A mobilidade do joelho foi severamente comprometida nos pacientes que realizaram o transporte femoral, o mesmo ocorrendo em relação ao tornozelo dos pacientes submetidos ao transporte tibial. Todos os pacientes com lesão na tíbia terminaram o tratamento com encurtamento do membro, o mesmo ocorrendo em 2 pacientes tratados devido a lesão femoral. Durante o tratamento nenhum paciente sentiu-se confortável e todos necessitaram de suporte para conseguir apoio parcial do membro. Todos pacientes ficaram satisfeitos com o resultado do tratamento. Concluímos que a resposta biológica ao transporte ósseo é formidável, com a formação do regenerado reparando grandes falhas ósseas. Entretanto, consideramos que o aparelho circular externo preconizado por llizarov traz consigo diversas complicações principalmente relacionadas a presença dos fios transfixantes, causando sofrimento para os pacientes, principalmente quando instalados no fêmur.

\section{SUMMARY}

Eleven patients carrying diaphyseal bone fissure secondary to ressection of infected bone segments, 5 in the femur and 6 in the tibia, submitted to the llizarov bone transport technique were retrospectively analyzed. In the group of patients with femoral lesion the bone fissure varied from $7 \mathrm{~cm}$ to $12 \mathrm{~cm}$, and in two there was a 2 $\mathrm{cm}$ shortening of the limb. In the group with tibial lesion the bone fissure varied from $2.5 \mathrm{~cm}$ to $10 \mathrm{~cm}$, with limb shortening in two patients, respectively $1.5 \mathrm{~cm}$ and $2 \mathrm{~cm}$. The mean follow-up period since the end of the treatment until evaluation was 49 months for the femoral lesion patients and 28.3 months for the tibial lesion patients. The femoral transports were bifocal and the tibial transports were bifocal in 4 patients and trifocal in 2. In all, patients formation of regenerate occurred. Consolidation of the target focus was naturally obtained in 7 patients; one patient needed bone grafting to obtain the focus consolidation. In three patients the nonunion of the target focus demanded modification of the treatment method with the external circular fixator withdrawal. In all the patients infection adjacent to the wires was observed. There was rupture of the wires in all assemblies made in the thigh. All the wires lost the tension initially imposed to them. Two patients submitted to femoral transport evolved with septic arthritis of the knee. Mobility of the knee was severely impaired in the patients submitted to femoral transport, and the same was observed in relation to the ankle of patients submitted to tibial transport. All the patients with tibial lesions finished treatment with limb shortening, as well as 2 patients treated due to femoral lesion. During treatment none of the patients felt comfortable and all needed help to achieve partial support of the limb. All the patients were satisfied with the result. We concluded that the biological response to bone transport is remarkable, with the regenerate formation repairing big bone fissures. However, we consider that the external circular device recommended by llizarov causes several complications mainly related to presence of transfixing wires, causing suffering to the patients mainly when installed in the femur. 


\section{INTRODUÇÃO}

llizarov demonstrou que a tração gradual sobre tecidos vivos origina cargas que podem estimular e manter o crescimento ativo e a regeneração de estruturas teciduais. Tecidos submetidos a uma tração lenta, mantida, tornam-se metabolicamente ativados, sendo o fenômeno caracterizado pela estimulação celular tanto biossintética como proliferativa. Denominou este principio de "lei da tensão de tração", salientando que este processo regenerativo depende de adequado suprimento sangüíneo e do efeito estimulante do suporte de carga (llizarov, 1989a-b) $)^{5,6}$.

Na realidade, llizarov demonstrou a formação direta de novo osso, que denominou de osso regenerado, no intervalo provocado pelo afastamento de dois fragmentos ósseos, desde que: 1) o afastamento dos fragmentos fosse gradual; 2) em determinada taxa e ritmo; 3) mantendo-se fixação estável dos fragmentos ósseos tracionados; 4) procurando-se evitar lesão periostal, da medula óssea e da artéria nutrícia central e seus ramos(llizarov, 1989a-b ) 5,6 .

A possibilidade de alongar o osso de forma segura e previsível, pela tração gradual segundo o princípio da "tensão de tração", possibilitou não somente o alongamento ósseo sob nova visão biológica, mas também levou ao desenvolvimento de uma nova técnica denominada de osteossíntese de compressão-afastamento. Com esta técnica corrige-se as falhas ósseas diafisárias. 0 comprimento do membro é mantido, ou se encurtado pode ser gradualmente alongado, através de uma corticotomia feita no osso sadio afastado da falha óssea. O segmento ósseo entre a falha e a corticotomia é fixado ao fixador circular externo de modo que é possível tracioná-lo enquanto os seguimentos ósseos nas extremidades da falha e da corticotomia são mantidos estáveis, ou, se necessário, podem também serem alongados. Quando a tração é aplicada no seguimento ósseo intercalado, criado pela corticotomia, este afasta-se do seguimento base e aproxima-se do fragmento alvo ocorrendo simultaneamente o afastamento da região da corticotomia e o fechamento do defeito ósseo original. Ocorre formação de regenerado dentro da zona de afastamento e o defeito é eliminado sem necessidade de enxerto (llizarov e Ledyaev, 1992) 8

Paley et al.(1989) ${ }^{12}$ denominaram esta osteossíntese de compressão-alongamento de alongamento interno ou transporte ósseo, desde que um defeito ósseo é preenchido pelo alongamento de um segmento ósseo sem alongamento concomitante do membro, embora isso possa ser feito.

llizarov preconiza esta técnica para corrigir os defeitos ósseos secundários a anomalias congênitas, ressecções tumorais, perda óssea traumática, ou como conseqüência do desbridamento em osteomielites com tecido ósseo inviável(llizarov, 1990) ${ }^{7}$.

Em 1988 começamos a utilizar o método de transporte ósseo preconizado por llizarov no Hospital das Clinicas da Faculdade de Medicina de Ribeirão Preto. Apresentamos a análise retrospectiva realizada em nossos pacientes.

\section{INTRODUCTION}

llizarov has shown that gradual traction on live tissues originates loads that can stimulate and maintain active growth and regeneration of the tissular structures. Tissues submitted to slow sustained traction become metabolically activated, and this phenomenon is characterized by both biosynthetic and proliferative cellular stimulation. He called this principle "law of the traction tension", emphasizing that this regenerative process depends on adequate blood supply and on the stimulating effect of load support (llizarov, 1989 a-b) 5, .

Actually, llizarov has shown the direct formation of new bone, that he called regenerated bone, in the interval provoked by the distanciation of two bony fragments since: 1) the fragments distanciation is gradual; 2) in a certain rate and rhythm; 3) maintains stable fixation of the bone fragments in traction; 4) is aimed to avoid periosteal lesion, of the bone marrow, and of the nutrient central artery and its branches (llizarov, 1989a-b) $)^{5,6}$.

The possibility to elongate securely and previsibly the bone by gradual traction according to the "traction tension" principle, possibilitated not only the bone lenghtening under a new biological view, but also led to the development of a new technique named compression-distanciation osteosynthesis. This technique corrects diaphyseal bone fissures. The lenght of the limb is maintained, or if it is shortened it can be gradually elongated, through corticotomy in the healthy bone distanced from the bone fissure. The bone segment between the fissure and the corticotomy is fixed to the external circular fixator in such a way that it is possible to traction it while the bone prolongation at the fissure and corticotomy edges are maintained stable or, if necessary, can also be elongated. When traction is applied in the intercalated bone prolongation, created by the corticotomy, it is distanced from the base prolongation and approaches the target fragment causing separation from the corticotomy region and closure of the original bone defect, simultaneously. Formation of regenerate occurs inside the distanciation zone and the defect is eliminated with no need of grafting (llizarov and Ledyaev, 1992) ${ }^{8}$.

Paley et al. (1989) ${ }^{12}$ referred to this compression-lenghtening osteosynthesis as internal lenghtening or bone transport, since the bone defect is filled by the lenghtening of a bone segment without concomitant lenghtening of the member, though this can be done.

Ilizarov recommends this technique to correct secondary bone defects and congenital anomalies, tumoral ressections, traumatic bone loss or as a consequence of débridement in osteomyelites with unviable bone tissue (llizarov, 1990)7.

In 1998, we started to use the bone transport method recommended by llizarov in the "Hospital das Clínicas", Ribeirão Preto College of Medicine. We present the retrospective analysis effected in our patients. 


\section{Casuística e Métodos}

De 1988 a 1994 implantamos o aparelho de llizarov com a finalidade de realizar o transporte ósseo em 14 pacientes. Somente em 11 pacientes conseguimos preencher o protocolo previamente elaborado para esta análise.

Dos 11 pacientes avaliados, 5 possuíam defeito ósseo diafisário femoral (F) e nos outros 6 o defeito era diafisário tibial (T).

O tempo médio de seguimento, desde a retirada do aparelho de llizarov até esta avaliação, é de 49 meses para os pacientes portadores de lesão femoral ( $F 1=90 ; F 2=18 ; F 3=81 ; F 4=10$; $\mathrm{F} 5=46$ meses) e de 28,3 meses para os pacientes portadores de lesão tibial ( $\mathrm{T} 1=17 ; \mathrm{T} 2=16 ; \mathrm{T} 3=38 ; \mathrm{T} 4=28 ; \mathrm{T} 5=39 ; \mathrm{T} 6=32$ meses).

Todos os pacientes eram masculinos, a idade variou entre $21 \mathrm{e}$ 35 anos $(M=27,7+/-6$ anos) para os defeitos femurais, e entre 20 e 49 anos ( $M=27,2+/-9,9$ anos) para os defeitos tibiais.

Acidente de transito foi responsável pela lesão em 10 pacientes, e uma lesão da perna foi decorrência de queda de cavalo.

Em três pacientes o trauma inicial provocou fratura fechada no fêmur, os outros dois eram portadores de fraturas expostas classificadas como tipo II e Illa conforme preconizado por Gustilo et al.(1984)4 . Cinco pacientes com lesão tibial inicialmente sofreram fraturas expostas tipo II, em 1 paciente a fratura era fechada.

Todos os pacientes foram submetidos a pelo menos uma cirurgia anteriormente á instalação do aparelho de llizarov, com média de três cirurgias para os pacientes portadores de lesão na coxa e de duas cirurgias para os portadores de lesão na perna.

Em todos os pacientes por nós tratados a falha óssea originouse secundariamente à ressecção de segmentos ósseos infectados.

Do grupo de pacientes com lesão femoral, em 3 deles não havia discrepância de comprimento inicial da coxa e a falha óssea presente era de $7 \mathrm{~cm}, 10 \mathrm{~cm}$ e de $12 \mathrm{~cm}$. Os outros 2 pacientes apresentavam encurtamento da coxa comprometida de 2,0 cm e a falha óssea presente era de $8 \mathrm{~cm}$ e $12 \mathrm{~cm}$ (tab.1).

\section{Casuistic and Methods}

From 1988 to 1994, we implanted the llizarov apparatus aiming to effect bone transport in 14 patients. Only in 11 patients we managed to fulfill the protocol previously elaborated for this analysis.

Among the 11 evaluated patients, 5 had femoral diaphyseal bone defect (F) and in 67 the defect was tibial diaphysis (T).

The mean follow-up period since llizarov's apparatus was withdrawn until this evaluation was 49 months for the patients with femoral lesion ( $F 1=90 ; F 2=18 ; F 3=81 ; F 4=10 ; F 5=46$ months) and 28.3 months for the patients with tibial lesion ( $T 1=17 ; T 2=16$; T3 = 38; T4 = 28; T5 = 39; T6 = 32 months).

All the patients were 21 to 35 year-old males ( $M=27.7+/-6$ years) with femoral defects and 20 to 49 year-old males $(M=27.2=/-9.9$ years) with tibial defects.

Car accidents were responsible for the lesion in 10 patients and a lesion in the leg was due to horse falling.

In three patients the initial trauma produced femur closed fractures and the other two had exposed fractures categorized as types II and IIla, according to Gustilo et al. (1984)4. Five patients with tibial lesion had initially open fractures type II and one patient had a closed fracture.

All the patients were submitted to at least one surgery before Ilizarov's apparatus was installed; three operations was the mean for the patients with thigh lesions and two for the ones with leg lesions.

In all the patients the bone fissure had secondarily been originated from the ressection of infected bone segments.

Among the patients with femoral lesions, three did not show discrepancy in the initial lenght of the thigh and the bone fissure had $7 \mathrm{~cm}, 10 \mathrm{~cm}$ and $12 \mathrm{~cm}$, respectively. The other 2 patients presented shortening of the thigh in $2.0 \mathrm{~cm}$ and the bone fissures were $8 \mathrm{~cm}$ and $12 \mathrm{~cm}$ (Table 1).

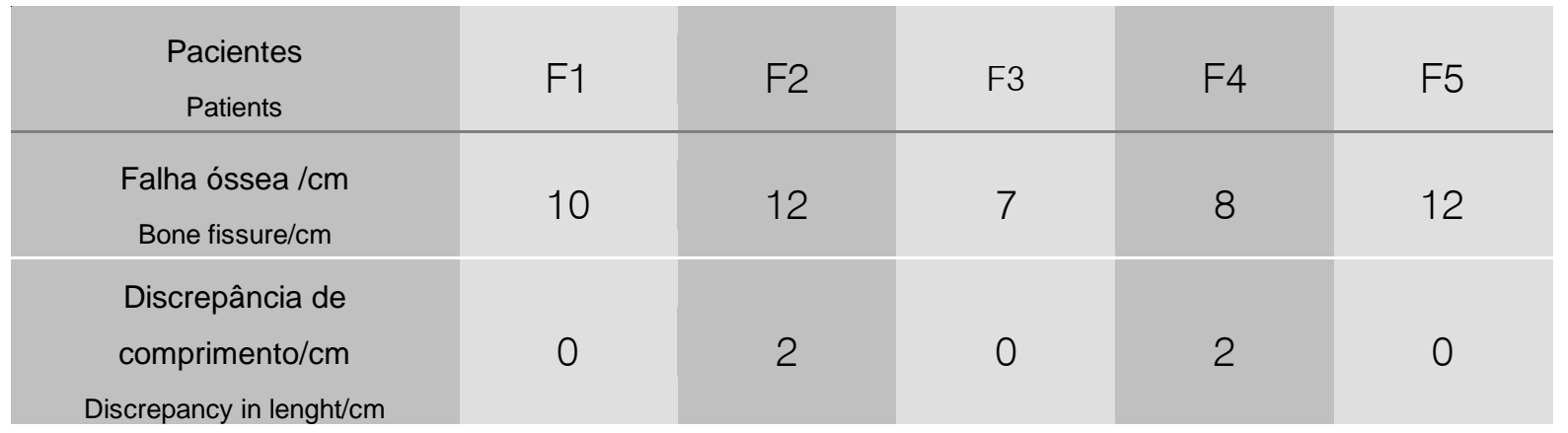

Tab.1- Falha óssea e discrepância de comprimento inicial nos pacientes portadores de lesão diafisária femoral. Table 1 - Bone fissure and discrepancy in the initial lenght of the femoral diaphyseal lesion patients.

Do grupo de paciente portadores de lesão na perna, em 4 deles não havia encurtamento da perna lesada e a falha óssea era de $2,5 \mathrm{~cm}, 4 \mathrm{~cm}, 8 \mathrm{~cm}$ e $10 \mathrm{~cm}$. Nos outros 2 pacientes a falha óssea era de $3,0 \mathrm{~cm}$ com encurtamento do membro lesado medindo $2 \mathrm{~cm}$ e $1,5 \mathrm{~cm}$ (tab.2).
Among the group of patients with leg lesions, 4 had no leg shortening and the bone fissures were $2.5 \mathrm{~cm}, 4 \mathrm{~cm}, 8 \mathrm{~cm}$ and 10 $\mathrm{cm}$. In the other 2 patients, bone fissure had $3.0 \mathrm{~cm}$ with the $2 \mathrm{~cm}$ and 1,5 cm limb shortening (Table 2) 


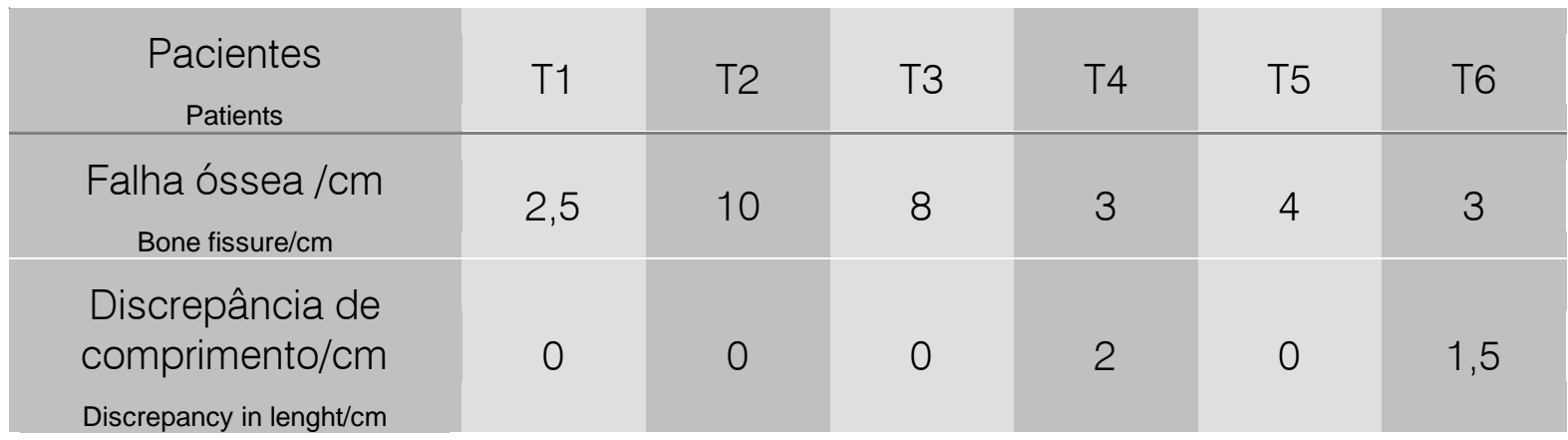

Tab. 2- Falha óssea e discrepância de comprimento inicial nos pacientes portadores de lesão diafisária tibial.

Table 2 - Bone fissure and discrepancy in the initial lenght of the tibial diaphyseal lesion patients.

Todos esses pacientes referiram não ter qualquer limitação da mobilidade articular previamente aos seus acidentes.

Em 4 pacientes com lesão femoral a falha óssea localizava-se predominantemente no terço médio diafisário (F1; F2; F3; F5), estando localizada no terço distal diafisário no outro paciente (F4). Em quatro pacientes com lesão tibial a falha óssea localizava-se predominantemente no terço distal diafisário (T1; T4; T5; T6), em um paciente a falha óssea localizava-se no terço médio diafisário (T3), no outro paciente (T2) a falha óssea localizava-se predominantemente no terço proximal diafisário.

Em todos os pacientes com lesão femoral o transporte foi do tipo bifocal, ou seja, um foco que era a falha pré existente e outro foco criado por uma corticotomia. A corticotomia foi realizada na região diafisária proximal em 3 pacientes (F1; F2; F4) e na região diafisária distal em 2 pacientes (F3; F5).

Em 4 pacientes portadores de lesão tibial (T1; T4; T5; T6) o tipo de transporte foi bifocal, ou seja, com apenas uma corticotomia. Nos outros 2 (T2; T3), o tipo de transporte foi trifocal, ou seja, além do foco próprio da falha óssea existente mais dois focos foram adicionados pela corticotomia. A corticotomia foi realizada na região diafisária proximal em 4 pacientes $(\mathrm{T} 1 ; \mathrm{T} 4 ; \mathrm{T} 5 ; \mathrm{T} 6)$, na região diafisária proximal mais na região diafisaria distal em 1 paciente(T3), e na região diafisária do terço médio mais na junção do terço distal para outro paciente(T2).

A fixação do fragmento principal proximal femoral foi feita utilizando-se um aro proximal e um clampe preso a ele, e em ambos prendiam-se fios de Schanz inseridos na região trocantérica e subtrocantérica. Em um paciente o fragmento principal proximal era longo e permitiu a colocação de um anel como forma de fixação adicional deste fragmento. O fragmento principal distal femoral foi estabilizado com dois anéis, e o fragmento a ser transportado foi fixado através de um anel.

Nos 4 pacientes portadores de lesão tibial em que o tipo de transporte realizado foi bifocal, os fragmentos principais (base e alvo) foram fixados cada um com dois anéis e o fragmento a ser
All the patients informed having no articular mobility limitation previous to the accidents.

In four patients with femoral lesion the bone fissure was predominantly located in the diaphysis middle third (F1; F2; F3; F5); it was located in the diaphysis distal third in the other patient (F4). In four patients with tibial lesion the bone fissure was predominantly located in the diaphysis distal third (T1; T4; T5; T6); in one patient the bone fissure was located in the diaphysis middle third (T3) and in another patient (T2) the bone fissure was located predominantly in the diaphysis proximal third.

In all the patients with femoral lesion transport was bifocal, that is, one focus that was the pre-existent fissure and other focus created by a corticotomy. Corticotomy was performed in the proximal diaphyseal region in 3 patients (F1; F2; F4) and in the distal diaphyseal region in 2 patients (F3; F5).

In 4 patients carrying tibial lesion (T1; T4; T5; T6) the type of transport was bifocal, that is, with only one corticotomy. In the other 2 (T2; T3) the kind of transport was trifocal, that is, besides the focus of the existent bone fissure, two more foci were added by corticotomy. Corticotomy was performed in the proximal diaphyseal region in 4 patients (T1; T4; T5; T6), in the proximal diaphyseal region and in the distal diaphyseal region in 1 patient (T3), and in the diaphyseal region in the middle third and in the distal third junction for the other patient (T2).

The fixation of the femoral proximal main fragment was done using a proximal ring and a clamp attached to it; to both Shanz wires were attached inserted in the tochanteric and subtrochanteric regions. In one patient the proximal main fragment was long and allowed the placement of a ring as a form of additional fixation for this fragment. The femoral distal main fragment was stabilized with two rings, and the fragment to be transported was fixed using one ring.

In the 4 patients with tibial lesion where the kind of transport was bifocal, the main fragments (base and target) were fixed with two rings each and the fragment to be transported was fixed with one 
transportado foi fixado com um anel. Em um deles(T6) adicionouse um semi-anel no retropé que unia-se aos anéis do fragmento principal distal visando aumentar a estabilidade da montagem.

A montagem variou nos 2 pacientes cujo transporte realizado foi trifocal. Em um deles, alem dos dois anéis nos fragmentos principais, cada fragmento transportável foi fixado com um anel. No outro paciente, o fragmento principal proximal foi fixado com dois anéis, o fragmento principal distal foi fixado com um anel que unia-se a um semi-anel fixado ao pé do paciente. Cada fragmento transportado fixou-se com um anel.

Todos anéis empregados uniam-se ao osso através de dois fios de Kirschner transfixantes de 1,8 mm de diâmetro para os fragmentos ósseos principais e de $1,5 \mathrm{~mm}$ de diâmetro para os fragmentos a serem transportados, sendo estes fios tensionados com auxilio de dinamômetros.

O transporte iniciava-se no decimo primeiro dia pós operatório, na taxa de 0,25 mm neste dia, 0,50 $\mathrm{mm}$ no segundo dia, 0,75 $\mathrm{mm}$ no terceiro dia e $1 \mathrm{~mm}$ no quarto dia e nos dias subsequentes divididos em quatro progressões de $0,25 \mathrm{~mm}$ de seis em seis horas.

\section{RESULTADOS}

Em todos nossos pacientes ocorreu formação do regenerado.

A consolidação entre o fragmento transportado e o fragmento alvo foi naturalmente obtida em sete pacientes. Um paciente com lesão femoral(F2), apresentou retarde de consolidação deste foco que consolidou após a colocação de enxerto ósseo.

Em outro paciente com lesão femoral, no terço médio diafisário (F5), não foi obtida a consolidação entre o fragmento transportado e o fragmento alvo proximal após onze meses de terminado o transporte ósseo.

Dois pacientes $(T 5, T 6)$, ambos com defeito ósseo diafisário no terço distal da tíbia e após quatorze meses e dezoito meses respectivamente de ter terminado o transporte ósseo, evoluíram com não-união entre o fragmento transportado e o fragmento alvo.

Uma vez uma vez que o tratamento não foi concluído com o fixador circular externo, sendo necessário mudar o método de estabilização dos focos não-unidos em três pacientes (F5; T5; T6) estes resultados são considerados em separado dos demais.

Em um paciente com lesão tibial(T2) a correção da falha óssea concomitantemente corrigiu a perda da cobertura cutânea.

Em três pacientes com lesão femoral ( F2; F3; F4 ) e em um paciente com lesão tibial(T4), a montagem inicial do fixador externo foi alterada ao final do transporte, basicamente consistindo em fixar o anel do fragmento transportado ao conjunto de anéis do fragmento alvo e, a seguir, a colocação de novas hastes unindo o conjunto fixador do fragmento base ao conjunto fixador dos fragmentos alvo e transportado de modo a permitir o alongamento ósseo através do regenerado visando corrigir discrepâncias de comprimento. ring. In one of them (T6) a semi-ring was added in the retrofoot which was united to the distal main fragment rings aiming to increase the assembly stability.

The assembly varied in 2 patients whose transport was trifocal. In one of them, besides the two rings in the main fragments, each transportable fragment was fixed with a ring. In the other patient, the proximal main fragment was fixed with two rings; the distal main fragment was fixed with one ring that was united to a semi-ring fixed to the patient's foot. Each transported fragment was fixed with a ring.

All the rings used were attached to the bone using two transfixant Kirschner $1.8 \mathrm{~mm}$ diameter wires for the bone main fragments and $1.5 \mathrm{~mm}$ diameter for the fragments to be transported, and these wires were tensioned with dynamometers.

The transport was started in the eleventh post-operatory day, in a $0.25 \mathrm{~mm}$ rate, in the first day, $0.50 \mathrm{~mm}$ in the second day, $0.75 \mathrm{~mm}$ in the third day, $1 \mathrm{~mm}$ in the fourth day and in the following days divided in four progressions of $0.25 \mathrm{~mm}$ in six-hour intervals.

\section{RESULTS}

In all the patients the regenerate was formed.

Consolidation between the transported fragment and the target fragment was naturally achieved in seven patients. One patient with femoral lesion (F2) presented delayed consolidation in this focus which has consolidated after the placement of bone grafting.

In other patient with a femoral lesion in the diaphysis middle third (F5) consolidation was not achieved between the transported fragment and the proximal target fragment eleven months after bone transport.

Two patients (T5, T6) both with diaphysis bone defect in the distal third of the tibia and fourteen months and eighteen months, respectively, after the bone transport, evolved with nonunion between the transported fragment and the target fragment.

As the treatment was not concluded with the external circular fixator, being necessary to change the stabilization method of the nonunited foci in three patients (F5; T5; T6) these results were separately considered.

In one patient with tibial lesion (T2) the bone fissure correction concomitantly corrected the loss of cutaneous lining.

In three patients with femoral lesion (F2; F3; F4) and in one patient with tibial lesion (T4), the initial assembly of the external fixator was altered at the end of the transport, basically consisting in fixing the transported fragment ring to the target fragment rings set and, then, placing of new shafts attaching the base fragment fixator set to the target and transported fragments fixator set as to allow bone lenghtening through the regenerate aiming to correct discrepancies in lenght. 
Todos os pacientes tiveram infecção no trajeto de pelo menos um fio de Kirschner transfixante, sendo necessário curativos locais e antibioticoterapia oral para melhorar as condições das partes moles adjacentes a este fio. Em três pacientes que usaram fios de Schanz houve secreções intermitentes, serosas e/ou purulentas por estes fios, também com necessidade de tratamento local e antibioticoterapia oral.

Houve quebras de fios de Kirschner da montagem do fixador em todos os pacientes com lesão na coxa, os quais foram substituídos. Nos pacientes reavaliados com lesão tibial os fios de Kirschner não quebraram. Todos os fios de Kirschner perderam a tensão que inicialmente Ihes foram imposta, sendo necessário retencioná-los ambulatorialmente através da manobra de soltar a porca, girar o parafuso que prendia o fio ao anel e reapertar a porca. A perda da tensão destes fios foi percebida pela palpação dos mesmos e, embora os fios presos aos fragmentos transportáveis parecessem mais firmes que os demais sempre exibiram um curvamento ao exame radiográfico que atestava que também estes tinham tendência a afrouxarem.

A montagem inicial em um paciente com lesão femoral ( F3 ) foi modificada objetivando melhorar a estabilidade da montagem. Este paciente posteriormente apresentou artrite séptica do joelho tratada com drenagem cirúrgica e antibioticoterapia.

Um dos pacientes com lesão femoral ( F2 ) trocou um fio de Kirschner quebrado, do anel distal, após seis semanas da instalação do aparelho de llizarov, sob anestesia local. Posteriormente submeteu-se a três bloqueios raquianos, sendo um para drenagem de artrite séptica do joelho direito e abscesso lateral da coxa direita e dois para troca de fios quebrados. Um quarto bloqueio raquiano foi necessário após terminado o transporte quando constatou-se que o fragmento transportado não mais encontrava-se comprimido contra o fragmento alvo, mas, pelo contrario, havia escapado dos dois fios de Kirschner que o mantinha e encontrava-se afastado do fragmento alvo com evidente deformação do regenerado retraído, sendo então passados dois novos fios de Kirschner no fragmento e reiniciado um novo transporte.

Tanto num paciente com lesão femoral ( F3 ) como em um dos pacientes com lesão tibial ( T3 ) a montagem teve que ser alterada sob bloqueio anestésico para corrigir desvio axial dos fragmentos transportados de modo a permitir um melhor contato quando da aproximação entre eles e os respectivos fragmentos alvo.

A tabela 3 mostra para cada paciente com lesão femoral a falha óssea correspondente em centímetros (A), o numero de dias gastos para realizar o transporte ósseo, o numero de dias que cada paciente permaneceu com o aparelho de fixação externa (B) e o índice de alongamento destes pacientes(B/A), excluindo-se o índice de transporte de F5 que não terminou o tratamento com o fixador circular externo. A tabela 4 mostra estes mesmos dados dos pacientes com lesão tibial excluindo-se o índice de transporte de T5 e T6 que não terminaram o tratamento com o fixador circular externo.
All the patients had infections along at least one of the transfixant Kirschner wires, and local dressings and oral antibioticotherapy were necessary to improve the condition of the soft parts adjacent to the wire. In three patients using Schanz wires there were intermitent serous and/or purulent secretions along the wires, also demanding local treatment and oral antibioticotherapy.

There were ruptures of the fixator assembly Kirschner wires in all patients with thigh lesions, and they were replaced. In the re-evaluated patients with tibial lesions the Kirschner wires did not break. All Kirschner wires lost the tension initially imposed to them, and it was necessary to tighten them in the ambulatory loosening the nut, turning the screw that attaches the wire to the ring and fastening the nut again. The loss of tension of these wires was noticed by palpation, and although the wires attached to the transported fragments appeared firmer than the others they always exhibited an incurvation in the radiographic examination attesting also that they too had a tendency to loosen.

The original assembly in one patient with femoral lesion (F3) was modified aiming to improve stability. Afterwards, this patient presented septic arthritis of the knee, which was treated by surgical drainage and antibioticotherapy.

One of the patients with femoral lesion (F2) changed a ruptured distal ring Kirschner wire six weeks after installation of the llizarov apparatus, under local anesthesia. Afterwards, he was submitted to three rachidian blockings, one for drainage of the septical arthritis of the right knee and lateral abscess of the right thigh and two to change the broken wires. A fourth rachidian blocking was necessary after transport when it was noticed that the transported fragment was not compressed against the target fragment but had escaped from the two Kirschner wires that sustained it and was far from the target fragment with evident deformation of the retracted regenerate; two new Kirschner wires were passed on the fragment and a new transport was started.

Both in a patient with femoral lesion (F3) and in another with tibial lesion (T3) the assembly had to be altered under anesthetic blocking to correct axial deviation of the transported fragments in order to allow a better contact when approximation was effected between them and the respective target fragments.

For the patients with femoral lesions Table 3 shows the corresponding bone fissure in centimeters $(A)$, the number of days necessary to effect the bone transport, the number of days each patients stayed with the external fixation apparatus (B), and the patients' index of lenghtening $(B / A)$, excluding the transport index for F5, who did not finish the treatment with the external circular fixator. Table 4 shows these data for the tibial lesion patients excluding the transport index for T5 and T6, who did not finish treatment with the external circular fixator. 


\begin{tabular}{|c|c|c|c|c|c|}
\hline $\begin{array}{l}\text { Pacientes } \\
\text { Patients }\end{array}$ & $\mathrm{F} 1$ & F2 & F3 & $\mathrm{F} 4$ & F5 \\
\hline $\begin{array}{l}\text { Falha óssea }(\mathrm{cm})(A) \\
\text { Bone fissure }(\mathrm{cm})(A)\end{array}$ & 10 & 12 & 7 & 8 & 12 \\
\hline $\begin{array}{c}\text { Tempo de transporte (dias) } \\
\text { Transport period (days) }\end{array}$ & 93 & 452 & 63 & 131 & 205 \\
\hline $\begin{array}{l}\text { Tempo de uso do aparelho (dias) (B) } \\
\text { Period using the apparatus (days) (B) }\end{array}$ & 289 & 640 & 468 & 433 & 527 \\
\hline $\begin{array}{c}\text { Índice de alongamento }(B / A)(\text { dias/cm) } \\
\text { Lenghtening index }(B / A)(\text { days/cm) }\end{array}$ & 28,9 & 53,3 & 66,8 & 54,1 & $\mathrm{NC}$ \\
\hline
\end{tabular}

Tab. 3 - Tamanho da falha óssea em centímetros(A), tempo de uso em dias do aparelho fixador externo gasto para realizar o transporte, tempo total em dias que o aparelho permaneceu no paciente(B), índice de alongamento (B/A) para cada paciente com lesão femoral. NC: Tratamento não completado com o fixador circular externo.

Table 3 - Bone fissure size in centimeters $(A)$, period of use of the external fixator apparatus necessary to effect transport, total period in days that the apparatus remained in the patients $(B)$, lenghtening index $(B / A)$ for the femoral lesion patients. NC: The treatment was not completed with the external circular fixator.

\begin{tabular}{|c|c|c|c|c|c|c|}
\hline $\begin{array}{c}\text { Pacientes } \\
\text { Patients }\end{array}$ & T1 & T2 & T3 & T4 & T5 & T6 \\
\hline $\begin{array}{c}\text { Falha óssea (cm) (A) } \\
\text { Bone fissure (cm) (A) }\end{array}$ & 2,5 & 10 & 8 & 3 & 4 & 3 \\
\hline $\begin{array}{c}\text { Tempo de transporte (dias) } \\
\text { Time of transport (days) }\end{array}$ & 215 & 162 & 287 & 21 & 50 & 107 \\
\hline $\begin{array}{c}\text { Tempo de uso do aparelho (dias) (B) } \\
\text { Period using the apparatus (days) (B) }\end{array}$ & 570 & 498 & 871 & 221 & 494 & 684 \\
\hline $\begin{array}{c}\text { Índice de alongamento (B/A) } \\
\text { Lenghtening index (B/A) }\end{array}$ & 228 & 49,8 & 108,8 & 73,6 & NC & NC \\
\hline
\end{tabular}

Tab. 4 - Tamanho da falha óssea em centímetros(A), tempo de uso em dias do aparelho fixador externo gasto para realizar o transporte, tempo total em dias que o aparelho permaneceu no paciente(B), índice de alongamento (B/A) para cada paciente com lesão tibial.

NC: Tratamento não completado com o fixador circular externo

Table 4 - Bone fissure size in centimeters $(A)$, period of use of the external fixator apparatus necessary to effect transport, total period in days that the apparatus remained in the patients $(B)$, lenghtening index $(B / A)$ for the tibial lesion patients. NC: The treatment was not completed with the external circular fixator.

A avaliação da mobilidade articular dos pacientes submetidos ao transporte ósseo femoral mostrou que em relação ao quadril a mobilidade encontrava-se normal em três pacientes (F1; F3; F4) enquanto que no quarto (F2)a flexão estava limitada a noventa graus. Quanto ao joelho, três pacientes (F1; F2; F3) realizavam flexão até trinta graus enquanto que no outro (F4) esta atingia dez graus. Em um destes pacientes (F4) o tornozelo e o pé tinham seus movimentos limitados, fato este atribuído ao trauma concomitante existente na perna.

A mobilidade articular do joelho dos pacientes submetidos ao transporte ósseo na tíbia encontrava-se normal (T1; T3; T4) com exceção de um paciente (T2) cuja flexão limitava-se a trinta graus, salientando-se que este sofreu fratura exposta tipo II no fêmur ipsilateral no mesmo acidente que gerou a lesão na perna.

Em relação ao tornozelo destes pacientes com transporte tibial encontramos que estava bloqueado em três deles (T1; T2; T3) e bastante limitado no outro (T4).
The articular mobility evaluation of the patients submitted to femoral bone transport showed that in relation to the hip mobility was normal in three patients (F1; F3; F4) while in the fourth patient (F2) flexure was limited to ninety degrees. Concerning the knee, three patients (F1; F2; F3) effected flexure until thirty degrees while in the other (F4) this reached ten degrees. In one of these patients (F4) the ankle and the foot had limited movements, and this was attributed to the concomitant trauma in the leg.

The knee articular mobility of the patients submitted to tibial bone transport was normal (T1; T3; T4) with the exception of one patient (T2) whose flexure was limited to thirty degrees pointing out that this patient had a type Il open fracture in the ipsilateral femur, which occurred in the same accident that caused the leg lesion.

Concerning the ankle of tibial transport patients, we noticed that it was blocked in three (T1; T2; T3) and very limited in the fourth (T4).

The articular mobility for $F 5, T 5$ and $T 6$ was not considered since the method of treatment was altered. 
A mobilidade articular para F5, T5 e T6 não foi considerada uma vez que o método de tratamento foi alterado.

Atrofia muscular evidente à inspeção clinica foi observada em todos os pacientes, sendo portanto resistente ao tratamento fisioterápico prescrito após a retirada do aparelho.

O escanograma realizado ao final do tratamento mostrou haver encurtamento do segmento tratado em dois pacientes com lesão femoral e em todos os pacientes com lesão na tíbia (tab. 5).
Muscular athrophy evident during clinical inspection was observed in all the patients, and resisted to physiotherapeutic treatment precribed after the apparatus withdrawal.

The scannogram performed at the end of the treatment showed that there was shortening of the treated segment in two patients with femoral lesion and in all patients with tibial lesion (Table 5).

\begin{tabular}{|c|c|c|c|c|c|c|c|c|}
\hline $\begin{array}{l}\text { Pacientes } \\
\text { Patients }\end{array}$ & $\mathrm{F} 1$ & F2 & F3 & F4 & $\mathrm{T} 1$ & $\mathrm{~T} 2$ & T3 & $\mathrm{T} 4$ \\
\hline $\begin{array}{l}\text { Discrepância final } \\
\text { Final discrepancy }\end{array}$ & 0 & 0,5 & 5,5 & 0 & 1 & 0 & 1 & 0,5 \\
\hline
\end{tabular}

Tab. 5 - Discrepância final em centimetros nos pacientes com lesão femoral (F) e tibial (T).

Table 5 - Final discrepancy in centimeters in patients with femoral (F) and tibial lesion (T).

Nenhum paciente sentiu-se confortável enquanto usou o fixador circular externo, nenhum conseguindo deambular com carga total do membro sendo necessário recorrer ao auxílio de muletas ou andadores. Ao final do tratamento todos os pacientes, tanto com lesão femoral como lesão tibial, são capazes de deambular sem auxílio de tutores, embora com claudicação evidente da marcha.

Em nenhum paciente a dor pode ser considerada responsável por esta claudicação, desde que apenas dois pacientes (F4; T1) a referiram como discreta e esporádica.

Todos os pacientes ficaram satisfeitos com o resultado do tratamento, atribuindo notas que numa escala de zero a dez variaram entre a menor 8,0 (T3) até 10,0 (F4; T1; T2) , obviamente excluindose F5, T5 e T6.

Quando indagados se usariam novamente o aparelho para transporte ósseo todos responderam afirmativamente, com exceção de um paciente com transporte femoral (F3).

As retrações cicatriciais da pele, embora com feio aspecto estético, não foram consideradas sequelas relevantes pelos pacientes.

Um paciente com lesão femoral (F3) e quatro com lesão tibial (T3; T4; T5; T6) desenvolveram dermatite ocre no segmento submetido ao transporte ósseo.

Edema crônico, persistente até o momento desta avaliação, foi observado no membro inferior dos pacientes com lesão femoral (F2; F3; F4) e na perna de quatro pacientes com lesão tibial(T3;T4; $\mathrm{T} 5 ; \mathrm{T} 6)$.

Um paciente (T2) referiu hipoestesia na região-medial da perna.

Em nenhum paciente cujo tratamento foi concluído com o fixador externo houve persistência de fistulas, embora em um transporte tibial (T6) houve formação de sequestro anelar no trajeto de um fio de Kirschner infectado.
None of the patients felt comfortable using the external circular fixator, none of them being able to walk with the total load of the limb; it was necessary to use crutches or walking aids. At the end of the treatment, all the patients, femoral or tibial, were able to walk without the aid of tutors, though with evident walking claudiacation.

In none of the patients pain can be considered responsible for this claudication, since only two patients (F4; T1) referred to it as discrete and sporadic.

All the patients were satisfied with the treatment result, attributing marks which in a zero to ten scale varied between the lowest 8.0 (T3) to 10.0 (F4; T1; T2) obviously excluding F5, T5 and T6.

When asked whether they would use the bone transport apparatus again all anwers were affirmative, with the exception of one patient with femoral transport (F3).

The cicatricial retractions of the skin, though presenting an ugly esthetic aspect, were not considered relevant sequelae by the patients.

One patient with femoral lesion (F3) and four with tibial lesions (T3; T4; T5; T6) developed ochrodermatitis in the bone transport segment.

Chronic edema, persistent till the moment this evaluation was effected, was observed in the lower limb of femoral lesion patients (F2; F3; F4) and in four legs of tibial lesion patients (T3; T4; T5; T6).

One patient (T2) reported hypoesthesia in the medial region of the leg.

In none of the patients whose treatment was concluded with the external fixator there was persistence of fistulas, though in one tibial transport (T6) there was formation of ring-shaped seclusion adjacent to an infected Kirschner wire. 


\section{DISCUSSÃO}

O resultado mais relevante do emprego do método preconizado por llizarov é, ao nosso ver, a formação do regenerado, obtida em todos pacientes tratados. Isto deve ser considerado levando-se em conta que até 1998 desconhecíamos a lei da "tensão de tração" demonstrada por llizarov, que começava a ser difundida pelo mundo ocidental onde a consolidação óssea conhecida era a direta, sob compressão e alta estabilidade entre os fragmentos ósseos e ausência de calo ósseo radiográfico, e a indireta na qual a instabilidade controlada entre os fragmentos permite a visualização radiográfica do calo ósseo. A formação do regenerado entre os fragmentos ósseos devidamente afastados possibilitou não só o alongamento ósseo e, portanto, do membro como um todo sob uma visão mais biológica como também a realização do transporte ósseo.

Atualmente o transporte ósseo é considerado o método de eleição para tratamento de grandes falhas ósseas, que são aquelas superiores a $4 \mathrm{~cm}$ de comprimento, uma vez que teoricamente qualquer tamanho de falha óssea pode ser corrigida pelo método (Paley et al. 1989'2; Mercadante e Santin, 199711).

Conseguimos eliminar a infecção e consequentemente as fístulas em todos os pacientes avaliados. Certamente isto foi possível graças a ressecção ampla de todo o osso considerado comprometido, quer seja avascular ou infectado, o que é permitido apenas pelo método do transporte ósseo.

A importância do regenerado também é valorizada por Paley et al. $\left(1989^{12}\right)$ após analisar 25 casos de transporte ósseo tibial realizados nas duas instituições médicas italianas pioneiras na utilização do método no ocidente, com o tamanho médio da falha de $6,2 \mathrm{~cm}$, variando de $1 \mathrm{~cm}$ a $23 \mathrm{~cm}$. Os resultados desta análise foram divididos em resultados ósseos e resultados funcionais. Para os resultados ósseos, quatro critérios foram avaliados: união, infecção, deformidade e encurtamento. Uma vez obtida a união óssea (aqui subentende-se também a formação do regenerado), o resultado ósseo seria excelente, bom ou regular, sendo considerado mau apenas se ocorresse não-união ou refratura. Obtiveram 18 resultados ósseos excelentes, com união óssea, ausência de infecção, deformidade angular inferior a $7^{\circ} \mathrm{e}$ encurtamento inferior a $2.5 \mathrm{~cm}$. Para o resultado considerado bom, além da união mais dois critérios presentes nos casos excelentes estavam aqui presentes e foi obtido em 5 pacientes. Nos casos considerados regulares, a união óssea foi obtida e mais um dos outros critérios presentes nos casos excelentes era encontrado, sendo este resultado encontrado em 2 pacientes. Nenhum paciente foi considerado mau resultado uma vez que todos obtiveram união óssea. Entretanto em 3 pacientes persistiu a drenagem purulenta, em 4 pacientes a deformidade angular residual era maior que $7^{\circ} \mathrm{e}$ em 1 paciente a discrepância de comprimento foi superior a 2,5 $\mathrm{cm}$.

Os resultados funcionais foram baseados em cinco critérios: claudicação significante à marcha, equinismo rígido do tornozelo, distrofia das partes moles, dor e inatividade. A inatividade, ou a incapacidade de reassumir as funções anteriormente exercidas, foi considerado o item mais importante desta análise. Para o resultado

\section{DISCUSSION}

The most relevant result using the method recommended by llizarov is, in our view, the formation of regenerate in all treated patients. This must be considered since until 1998 Ilizarov's "tension of traction" law was unknown to us and beginning to diffuse in the Western world where bone consolidation as we knew it was direct, under compression and high stability among the bone fragments with no radiographic bone callus, and indirect, where controlled instability among the fragments allows radiographic visualization of the bone callus. The formation of the regenerate among bone fragments adequately separated possibilitated not only bone lenghtening and consequently limb lenghtening as a whole under a more biological view but also to perform bone transport.

Nowadays, bone transport is considered the method of choice to treat big bone fissures more than $4 \mathrm{~cm}$ long, since theoretically any size of bone fissure can be corrected by the method (Paley et al. 1989²; Mercadante e Santin, 1997¹).

We managed to eliminate infection and consequently the fistulas in all the evaluated patients. Certainly this was made possible thanks to ample ressection of all affected bone, whether avascular or infected, permitted only by the bone transport method.

The importance of the regenerate is also emphasized by Paley et al. (1989'12) after analyzing 25 cases of tibial bone transport, fissures sized $1 \mathrm{~cm}$ to $23 \mathrm{~cm}$, average $6.2 \mathrm{~cm}$, carried out in two Italian medical institutions pioneer in the utilization of the method in the Western world. The results of this analysis were divided in bone results and functional results. For the bone results, four criteria were evaluated: union, infection, deformity and shortening. Achieving bone union (here including also the formation of the regenerate), the results would be excellent, good or regular, being considered bad only if nonunion or re-fracture occurred. Eighteen excellent bone results were obtained, with bone union, absence of infection, angular deformity inferior to $7^{\circ}$ and shortening inferior to $2.5 \mathrm{~cm}$. Good results were obtained in 5 patients where, besides union, two more criteria present in the excellent cases were present. In the cases considered regular, bone union was obtained and one more of the criteria present in the excellent cases was found; this result was seen in 2 patients. None of the patients was considered as a bad result since all showed bone union. However, in three patients, a purulent drainage persisted, in 4 patients residual angular deformity was higher than $7^{\circ}$ and in one patient discrepancy of lenght was superior to $2.5 \mathrm{~cm}$.

The functional results were based in five criteria: significant walking claudication, rigid equinism of the ankle, dystrophy of the soft parts, pain and inactivity. Inactivity or inability to resume previously exerted functions was considered the most important item in this analysis. In order that the result is considered excellent, the patient must be active and must not present any other considered criteria. The result is considered good when the patient, besides being active, presents one or two of the other criteria. The result is regular when the patient is active and three or all other criteria are present. An inactive individual is considered a bad result in spite of the presence or absence of the other pre-established criteria. All the 25 patients evaluated resumed work and their daily activities and, based in these criteria, 16 patients 
ser excelente, o paciente deveria ser ativo e não ter qualquer outro dos critérios considerados. Para o resultado ser bom o paciente, além de ativo, apresentava um ou dois dos outros critérios considerados. Como resultado regular foi considerado o paciente ativo com três ou todos os outros critérios considerados presentes. O indivíduo inativo foi considerado como mau resultado independentemente da presença ou ausência dos demais critérios pré-estabelecidos. Todos 25 pacientes avaliados retornaram ao trabalho e as suas atividades diárias e portanto, baseados nestes critérios, 16 pacientes foram enquadrados nos resultados funcionais como excelente, 7 foram bons, 1 foi regular e 1 mau. No entanto, 4 pacientes apresentavam claudicação importante á marcha, 5 apresentavam equinismo fixo do tornozelo, 4 persistiram com distrofia de partes moles e dor, e 1 paciente evoluiu para amputação devido a disestesias secundária a lesão do nervo tibial posterior.

Referem ainda que obtiveram melhora da mobilidade articular quando comparada com aquela pré-existente ao tratamento, sendo a melhora obtida em 7 pacientes tanto do joelho como do tornozelo, em 7 pacientes apenas a mobilidade do joelho, em 5 pacientes apenas a mobilidade do tornozelo.

Em relação as complicações observadas, Paley et al.(1989) ${ }^{12}$ referem que seis pinos quebraram em dois pacientes e que em cinco pacientes nove pinos tiveram que ser removidos devido a infecção, mas não encontraram nenhum sequestro anelar no trajeto destes pinos infectados.

Dividiram as dificuldades encontradas nas seguintes três áreas: obstrução do trajeto percorrido pelo fragmento transportado pelas partes moles observado em dois pacientes; retarde na consolidação do regenerado observado em um paciente e retarde na consolidação do foco alvo observado em oito pacientes. Relacionaram o retarde de consolidação do regenerado à instabilidade do aparelho fixador, enquanto o retarde de consolidação do foco alvo relaciona-se a problemas biológicos como: mal contacto entre os fragmentos neste foco; falta de estimulo osteogênico no extremo distal do fragmento transportado; e a presença de osso morto interposto. A impressão destes autores (Paley et al., 1989) ${ }^{12}$ é de que o índice de transporte destes pacientes variou entre 30-40 dias/cm, índice similar ao encontrado nos alongamentos dos membros.

Paley et al.(1989) ${ }^{12}$ discutem seus resultados levando em consideração a gravidade dos pacientes tratados, considerados os casos mais difíceis de não-união entre os mais de cem pacientes tratados na Itália, sendo metade destes pacientes cronicamente infectados, com 88\% deles exibindo os extremos ósseos atróficos, submetidos em média a três cirurgias prévias devido as lesões que portaram em média 3,5 anos antes deste tratamento. Referem que, embora seus resultados representem a experiência inicial do método no mundo ocidental, são comparados favoravelmente com aqueles reportados pela própria instituição de llizarov e por outros centros soviéticos.

Também achamos importante considerar que todos pacientes por nós tratados são adultos jovens, na fase produtiva de suas vidas, vítimas de lesões graves secundárias ao alto impacto do trauma recebido, com desenvolvimento posterior de infecção óssea cuja ressecção provocou as grandes falhas ósseas a serem tratadas com média de 9,2cm no fêmur e de 5,8cm na tíbia, e que were considered according to the functional results as excellent, 7 good, 1 regular and 1 bad. However, 4 patients presented important walking claudication, 5 fixed equinism of the ankle, 4 had persistent dystrophy of the soft parts and pain and 1 patient evolved to amputation due to disesthesia secondary to lesion of the posterior tibial nerve.

The patients also mention that the articular mobility improved as compared to the pre-existent one, and improvement both in the knee and the ankle was obtained in 7 patients, knee mobility only in 7 patients and ankle mobility only in 5 patients

Concerning complications, Paley et al $\left(1989^{12}\right)$ report that six pins broke in two patients and that in five patients nine pins had to be removed due to infection but no ring-shaped seclusion was found along these infected pins.

The difficulties found were divided in three areas: obstruction along the way of the transported fragment through the soft parts in two patients, retardation of the regenerate consolidation observed in one patient, and retardation of the target focus consolidation observed in eight patients. Retardation of the regenerate consolidation was related to instability of the fixator device, while retardation of the target focus consolidation was related to biological problems as poor contact between the fragments in this focus, lack of osteogenic stimulus in the distal end of the transported fragment, and presence of interposed dead bone. The opinion of these authors (Paley et al., 1989'2) is that the transport index in these patients varied from 30 to 40 days $/ \mathrm{cm}$, similar to the index found in limb lenghtenings.

Paley et al. (1989) ${ }^{12}$ discuss their results considering the severity of the treated patients' condition, the more difficult cases being considered nonunion in more than a hundred of patients treated in Italy, half of them chronically infected, 88\% exhibiting athrophic bone extremities, submitted to three previous operations on average due to lesions they carried 3.5 years on average before this treatment. They mention that, though the results represent the initial experience with the method in the Western world, they can be favorably compared with those reported by llizarov's institution and by other Soviet Union centers.

We also consider important to consider that all the patients we treated are young adults, in the productive phase of their lives, victims of severe lesions secondary to the high impact of the trauma they received, with the posterior development of bone infection whose ressection provoked the big bone fissures to be treated averaging $9.2 \mathrm{~cm}$ in the femur and $5.8 \mathrm{~cm}$ in the tibia, and that previously had been submitted to at least one operation denoting fruitless tentatives that prolonged the time treating their lesions. The bone transport we proposed to these patients was a procedure to save the limb, outlining that in case of failure the probable alternative would be amputation, considering not only the bone lesion but also the soft parts associated deterioration.

Within the context ot treating such severe lesions, it is noteworthy to observe the formation of the regenerate in all our patients and remmission of the infection. However, after retrospectively analyzing our results, we noticed that the regenerate formation only does not imply in obtaining satisfactory results as far as bone reconstruction is concerned, since we observed the difficulty of the target focus to 
anteriormente tinham sido submetidos a pelo menos uma cirurgia denotando tentativas infrutíferas que prolongaram ainda mais o tempo em que permaneceram tratando suas lesões. O transporte ósseo que propussemos a estes pacientes foi como procedimento de salvamento do membro, realçando que caso o método falhasse a alternativa provável seria a amputação, considerando não só a lesão óssea mas também o comprometimento associado das partes moles.

Dentro deste contexto, do tratamento de tão graves lesões, é notável a constatação da formação do regenerado, observado em todos nossos pacientes, e o desaparecimento da infecção. Entretanto, ao final da análise retrospectiva de nossos resultados, percebemos que somente por si a formação do regenerado não implica em obter resultados satisfatórios no tocante a reconstrução óssea, uma vez que observamos a dificuldade de consolidação do foco alvo. Em três pacientes não conseguimos obter a consolidação do foco alvo (um fêmur, duas tíbias), além de um outro fêmur cujo retarde de consolidação evoluiu favoravelmente após o uso de enxerto autólogo .

Comparando nossos resultados com os critérios estabelecidos por Paley et al.(1989) ${ }^{12}$ de resultados ósseos, teríamos pelo menos $27,2 \%$ de resultados ósseos insatisfatórios considerando apenas os casos não-unidos do foco alvo, embora não tivéssemos persistência de fistulas, deformidades angulares merecedoras de atenção e apenas um caso de lesão femural com encurtamento maior que $2,5 \mathrm{~cm}$. Considerados em separado, os resultados ósseos seriam insatisfatórios em 33,3 dos transportes tibiais e de $20 \%$ para os transportes femorais. Embora o método preconizado por llizarov desconsidere o emprego do enxerto ósseo, baseado no fato que a corticomia tem o efeito de aumentar o fluxo sanguíneo da região onde é realizada (Paley et al., 198912; Schwartsman et al., $1990^{13}$ ), nossos resultados indicam que o emprego do enxerto esponjoso autólogo no foco alvo do transporte ósseo viria estimular a consolidação deste foco e, deste modo, abreviar o tempo de uso do aparelho, tal qual preconizado por Green(1994) ${ }^{3}$.

Uma das áreas críticas do transporte ósseo tibial segundo Paley et al. (1989) ${ }^{12}$ é o retarde de consolidação do regenerado, apesar de o terem observado em apenas um paciente, e afirmarem não ser um problema comum se a estabilidade do aparelho for mantida.

A corticalização do regenerado não foi um problema que nos preocupou durante o transporte ósseo, uma vez que tivemos maior dificuldade em obter a consolidação do foco alvo. Isto pode ser visto pelo tempo de uso do aparelho em nossos pacientes que em média durou 18 meses na tíbia e 15.2 mêses no fêmur, enquanto Paley et al. (1989) ${ }^{12}$ concluíram o tratamento tibial em tempo médio de 13.6 mêses. Enquanto Paley et al. (1989)12 tiveram a impressão de gastar 30-40 dias para cada centímetro de regenerado obtido, nós gastamos 50,7 dias/cm no transporte femoral e 115 dias/cm no transporte tibial. Green $(1994)^{3}$ gastou em média 1,9 mêses por centímetro do defeito tibial tratado pelo transporte ósseo. O maior tempo de uso do aparelho em nossos pacientes é atribuído ao problema da instabilidade da armação que tivemos. A tortuosidade do regenerado devido à instabilidade da armação pode ser comprovada quando da soltura do fragmento de transporte dos consolidate. In three patients we failed in obtaining consolidation of the target focus (one femur, two tibias), and in another femur retardation evolved favorably after the use of autologous grafting.

Comparing our results with the criteria established by Paley et al. (1989) ${ }^{12}$ for bone results, we would have at least $27.2 \%$ insatisfactory bone results considering only the nonunion cases of the target focus, though we have not observed persistence of the fistulas, angular deformities deserving attention, having only one case of femoral lesion with more than $2.5 \mathrm{~cm}$ shortening. Considered separately, the bone results would be insatisfactory in 33.3 of the tibial transport and $20 \%$ for the femoral transport. Though the method recommended by llizarov desconsiders the use of the bone grafting, based in the fact that corticotomy exerts the effect of increasing blood flow in the region where it is carried out (Paldy et al., 198912; Schwartsman et al., $\left.1990^{13}\right)$, our results indicate that the use of the autologous spongy bone graft in the bone transport target focus would stimulate consolidation of this focus and, thus, would abbreviate the period the apparatus would be used, as recommended by Green (1994)³.

One of the critical areas of tibial bone transport according to Paley et al. (1989) ${ }^{12}$ is retardation of the regenerate consolidation, although they have observed it in only one patient stating that it is not a common problem if the apparatus stability is maintained,

Corticalization of the regenerate was not a problem to worry us during bone transport, since we had more difficulty in obtaining consolidation of the target focus. This can be observed by the period the apparatus was used by our patients, on average 18 months in the tibia and 15.2 months in the femur, while Paley et al. (1989) ${ }^{12}$ concluded the tibial treatment in 13.6 months on average. While Paley et al. (1989) ${ }^{12}$ spent 30 to 40 days for each centimeter of regenerate, we spent 50.7 days/cm in femoral transport and 115 days/cm in tibial transport. Green (1994) ${ }^{3}$ spent on average 1.9 months per centimeter of tibial defect treated by bone transport. The extense period of use of the apparatus by our patients is attributed to instability of the frame we used. Tortuosity of the regenerate due to frame instability could be evidenced when the transport fragment got loose from the tightening wires in one patient with femoral lesion. However, in the patients where the assembly was more stable the period of use was shorter, while in the patients with less stability the period of use was longer; nevertheless, the regenerate has been formed in all of them. Instability was consequence both to loss of tension in the wires and by rupture of the wires mainly after they had been re-tensioned by turning the screw. Leivas et al. (1996) ${ }^{9}$ clearly demonstrated that the screws we use are ineffective to maintain the Kirschner wires tense. As practically all the wires lost their original tension and not all presented secretions, it was not possible to relate this fact to the presence of infection along them.

It is interesting that the wires attached to the transported fragment are the ones that better maintain tension, although they have to open their way through the soft parts. It is probable that the resistance offered by the soft parts adherent to this fragment and by the regenerate help to maintain the wires tension. Though curved, with the central portion attached to the fragment being transported and the extremities attached to the rings deviated in direction of the target fragment, during palpation of the wires effected in the ambulatory, they were 
fios que o prendiam em um paciente com lesão femoral. No entanto, naqueles pacientes nos quais a montagem permaneceu mais estável o tempo de uso do aparelho foi menor, enquanto que nos pacientes com perda da estabilidade o tempo de uso foi maior, apesar de em todos eles ter se formado o regenerado. A instabilidade foi gerada tanto por perda da tensão nos fios, como pela quebra dos fios principalmente após terem sido retensionados pela manobra de girar o parafuso. Leivas et al. (1996) ${ }^{9}$ demonstraram claramente que os parafusos que utilizamos são ineficazes para manter os fios Kirschner tensos. Como praticamente todos os fios perderam a tensão original, e nem todos apresentaram secreções, não nos é possível relacionar-mos este fato com a presença de infecção nos seus trajetos.

Interessante é que os fios presos ao fragmento transportado são os que melhor mantêm a tensão, apesar de terem que abrir caminho através das partes moles. É provável que a resistência oferecida pelas partes moles aderidas a este fragmento e pelo regenerado ajudem a manter a tensão nestes fios. Apesar de curvados, com a porção central presa ao fragmento em transporte e as pontas presas aos anéis desviadas no sentido do fragmento alvo, durante à palpação dos fios realizados ambulatorialmente, estes apresentavam-se aparentemente mais tensos que os demais fios.

Também existe tendência à soltura de todos parafusos que travam cada peça da armação. O reaperto de cada parafuso contra sua porca deve ser feito diariamente pelo paciente, sendo de mais fácil controle que o afrouxamento dos fios.

O fato de utilizarmos vários pinos de Schanz no fêmur proximal, e sempre dois anéis com dois fios nos fragmentos principais, não implica em obter-se uma montagem estável, devido a tendência natural ao afrouxamento dos diversos componentes do aparelho.

Nos parece que o maior problema do transporte ósseo é manter a estabilidade da armação. O desconforto referido por todos nossos pacientes estava relacionado tanto ao grande tamanho da armação como também pela presença da dor, gerada a nosso ver pela instabilidade da armação. Schwartsman et al. (1990) ${ }^{13}$ também referem a presença de dor e a pouca aceitação do aparelho pelo paciente durante o tratamento de não-união da tíbia.

Green $(1994)^{3}$ considerou o aparelho de llizarov, aplicado com fios de aço transfixantes, como um passo para trás no progresso clínico, quando levou em consideração a tolerância ao aparelho pelo paciente e pelo médico.

Definitivamente, ao longo do tratamento, o paciente já não suporta mais o aparelho, que por sua vez tende a não suportar as cargas que Ihe são impostas, tornando-se apenas suportável a relação médico-paciente, principalmente quando é aplicado na coxa.

A vontade de retirar o aparelho deve ser refreada até que ocorra a corticalização do regenerado. Achamos que a retirada precoce do aparelho tenha sido responsável pelo encurtamento final de 5,5cm observado em um paciente (F3).

Dois pacientes submetidos ao transporte femoral tiveram pioartrite do joelho. Achamos provável que a pioartrite tenha sido secundária a infecção do trajeto dos fios próximos ao joelho, o que piora sobremaneira o resultado final. aparently more tense than the other wires.

The screws that fix the pieces of the assembly also have tendency to loosen. Tightening of the screws and nuts must be effected everyday by the patient, and its control is easier than the loosening of the wires.

Using several Schanz pins in the proximal femur and always two rings with two wires in the main fragments does not imply in obtaining a stable assembly, due to the natural tendency to loose of the several components of the apparatus.

It seems to us that the more important problem of bone transport is to maintain stability of the assembly. The discomfort mentioned by all our patients was related to the big size of the assembly and to pain, generated by its instability. Schwartsman et al. (1990) ${ }^{13}$ also mention pain and poor acceptance of the apparatus by the patients during tibial nonunion treatment.

Green (1994) ${ }^{3}$ considered Ilizarov's apparatus, applied with transfixant steel wires as a step back in clinical progress, when he considered the patients' and the doctors' tolerance.

Definitively, during treatment, the patient does not tolerate the apparatus, whose tendency is not to bear the loads imposed to it; the relationship doctor-patient is barely endurable mainly when the apparatus is applied to the thigh.

Withdrawal must be retarded until regenerate corticalization occurs. Early withdrawal of the apparatus in our opinion was responsible for the final $5.5 \mathrm{~cm}$ shortening observed in one patient (F3).

Two patients submitted to femoral transport had knee pyoarthritis. The probability exists that this condition was secondary to infection along the wires near to the knee, somewhat deteriorating the final result.

Paley et al. (1989) ${ }^{12}$ consider that the great disadvantage of the patient's intolerance to the external fixator is of little relevance when one considers the difficult problem to be treated.

Actually, the patient candidate to bone transport represents a difficult problem. However, we do not agree that intolerance to the apparatus must be left aside, since the different complications are related to the presence of transfixant wires and loosening of the apparatus and of the wires. The biological efficacy of the method is praised in the classification proposed by Paley et al. (1989)12, considering the formation of regenerated bone and the relevant factor of the bone accomplished results, and we agree. However, the functional results give value to the fact that the patients resume their activities, and we do attribute importance to this in view of the great influence the individual social context exerts in order that they resume their previous occupation. Improvement of articular mobility in the patients treated by Paley et al. (1989) ${ }^{12}$ is beyond our comprehension since a great diminution in the knee mobility has occurred in our patients submitted to femoral transport, and because the ankle practically became rigid in the patients submitted to tibial transport. Green (1994) has also observed muscular contracture in seven patients, two in the hip, two in the knee and three equinovarus, among seventeen he treated with bone transport. The big discomfort caused by the apparatus, the infections along the wires which cause pyoarthritis near the joints, the intermitent secretion, the broken wires and the loosening of the apparatus causing pain, the rigidity of the knee after femoral transport and of the ankle after tibial transport, muscular athrophy of the limb persisting after the end ot treatment, chronic 
Paley et al. (1989) ${ }^{12}$ consideram que a grande desvantagem da intolerância do paciente ao fixador externo deve ser de pequena relevância diante de tão difícil problema a ser tratado.

Realmente o paciente candidato ao transporte ósseo apresenta um difícil problema a ser resolvido. Mas não concordamos que a intolerância ao aparelho deva ser relegada a um segundo plano, uma vez que as diferentes complicações relacionam-se com a presença de fios transfixantes e afrouxamento do aparelho e dos fios. O fato do método ser biológicamente eficaz é reverenciado na classificação proposta por Paley et al. (1989) ${ }^{12}$, considerando a formação do osso regenerado o fator relevante do resultado ósseo obtido, com o que concordamos. No entanto, os resultados funcionais valorizaram o fato do paciente reassumir suas atividades, o que não consideramos importante tendo em vista a grande influência do contexto social do indivíduo para reassumir seu trabalho anterior. A melhora da mobilidade articular nos pacientes tratados por Paley et al. (1989) ${ }^{12}$ para nós é incompreensível, visto que nos nossos pacientes submetidos ao transporte femoral ocorreu grande diminuição da mobilidade do joelho, e nos pacientes submetidos ao transporte tibial praticamente o tornozelo tornou-se rígido. Green (1994) ${ }^{3}$ também observou contratura muscular em sete pacientes dos dezessete que tratou realizando transporte ósseo, sendo dois no quadril, dois no joelho e três equinovaros. O grande desconforto provocado pelo aparelho, as infecções provocadas no trajeto dos fios, que próximos as juntas provocam pioartrites, as secreções intermitentes, as quebras dos fios e afrouxamento do aparelho que provocam dor, a rigidez do joelho quando do transporte femoral e do tornozelo quando do transporte tibial, a atrofia muscular do membro que persiste após o final do tratamento, o edema crônico com dermatite ocre, as feias retrações cicatriciais, a evidente claudicação à marcha, o encurtamento do membro, são fatores que não podem ser desconsiderados ou tornados de menor importância. São complicações reais, que ocorreram nos nossos pacientes e algumas delas nos pacientes de Paley et al. (1989) ${ }^{12} \mathrm{e}$ que embora não sirvam para ofuscar o brilhantismos da formação do regenerado nestes pacientes, não devem ser relegadas a um segundo plano e sim devemos nos precavermos contra elas e procurarmos evitá-las. Catagni e Felici(1996)² após reavaliarem 20 pacientes com falha óssea média de $8,4 \mathrm{~cm}$ tratados num dos centros italianos que fez parte do levantamento realizado por Paley et al. (1989) ${ }^{12}$ concluíram que para os transportes realizados na tíbia o uso de duas corticotomias melhora o resultado obtido, diminuindo tanto a quantidade de partes moles a ser atravessadas pelos fios do fragmento em transporte como o tempo de uso do aparelho. Referem que quinze pacientes tiveram revisão cirúrgica visando melhorar a aproximação dos fragmentos transportados, quatro pacientes utilizaram enxerto ósseo, e que o método de llizarov proporcionou resultados satisfatórios comparáveis aos obtidos por Paley et al.(1989) ${ }^{12}$.

As notas que os pacientes deram relativas a satisfação com o resultado do tratamento foram surpreendentemente altas, se considerarmos as queixas e sofrimentos passados durante 0 tratamento. Três pacientes expontâneamente responderam que prefeririam este tratamento à amputação, e talvez a explicação inicial dada a eles de que a falha do método resultaria em amputação seja edema with ochrodermatitis, the ugly cicatricial retraction, the evident walking claudication, the shortening of the limb, are factors which cannot be disconsidered or considered as having little importance. Actual complications, which occurred in our patients and some of Paley's patients as well $(1989)^{12}$, cannot discredit the regenerate formation in these patients and must not be relegated to a secondary place but we have to be cautious and avoid them. Catagni and Felici (1996) ${ }^{2}$ after re-evaluating 20 patients with $8.4 \mathrm{~cm}$ middle bone fissure, treated in the Italian centers mentioned by Paley et al. (1989) ${ }^{12}$ concluded that in tibial transports two corticotomies improve the result, diminishing both the quantity of soft parts to be transversed by the wires of the transport fragment and the period the apparatus is used. They mention that fifteen patients had a surgical revision aiming to improve approximation of the transported fragments, four patients had bone grafts and that Ilizarov's method propitiated satisfactory results comparable to Paley's et al. (1989)12.

The patients' marks concerning satisfaction with the results were remarkably high if we consider the complaints and suffering they endured during the treatment.

Three patients spontaneously stated that they preferred this treatment to amputation and maybe the initial explanation given to them that failure would result in amputation had been responsible for the high marks since the limb was preserved, free from bone infection.

One patient did not consider relevant the final $5.5 \mathrm{~cm}$ shortening of his limb, however he and another patient, both submitted to femoral transport, would prefer another method, mainly due to suffering and infections which appeared during the use of the apparatus.

We consider worthwhile to mention the fact that in one patient submitted to tibial transport bone fissure was accompanied by a cutaneous lining flaw and during transport the transported fragment brought together the soft parts that covered it healing the wound and avoiding plastic surgeries to cover it.

One has to consider that the bone transport method is frequently used by the Brazilian surgeons, however, the results are poorly divulged. Even the English literature is poor concerning femoral bone transport, and all the papers we had in hand mentioned tibial transport. It is likely that the thickness of the soft parts, which involve the femur discourage the use of transfixant wires, mainly when these wires are displaced as it is the case in the femoral transport. However, in our patients submitted to femoral transport, we did not observe the clinical complications caused by inadequate placement of pins or wires, as nerve and vessel lesions, syndromes of compartment or others previously mentioned by Behrens (1989) ${ }^{1}$. Mercadante $(1997)^{10}$ and Mercadante and Santin (1997) ${ }^{11}$ obtained 95\% satisfactory results in 18 patients submitted to bone transport of the leg. They consider bone transport a revolutionary method, which enables tissular neogenesis induction consequently allowing treatment of big bone fissures. They evaluated their results by the parameters proposed by Paley et al. (1989) ${ }^{12}$ just as all the publications found in extensive bibliographic revision (Mercadante, 1997) ${ }^{10}$. However, they think that a new systematic for evaluation should be instituted, since they consider that the evaluation of the results based on the parameters proposed by Paley et al. (1989) ${ }^{12}$ is complacent and tolerant, and we totally agree. 
responsável pelas altas notas atribuídas, uma vez que o membro foi preservado, livre da infecção óssea.

Um paciente não considerou relevante o encurtamento final de $5,5 \mathrm{~cm}$ no seu membro, mas tanto este como um outro, ambos submetidos ao transporte femoral, dariam preferencia a outro método de tratamento, principalmente devido ao sofrimento e infecções surgidas durante o uso do aparelho.

Embora observado em apenas um paciente submetido ao transporte tibial, consideramos digno de ser ressaltado o fato que neste paciente a falha óssea era acompanhada de falha de cobertura cutânea, e durante o transporte o fragmento transportado trouxe consigo as partes moles que o cobriam permitindo o fechamento da ferida sem necessidade de cirurgias plásticas de cobertura.

Deve ser considerado que o método de transporte ósseo é bastante utilizado por cirurgiões brasileiros, mas os resultados obtidos são pouco divulgados. Mesmo a literatura mundial inglesa é pobre no tocante ao transporte ósseo femoral, sendo que a totalidade dos trabalhos aos quais tivemos acesso referem-se ao transporte tibial. É provável que a espessura das partes moles que envolvem o fêmur desestimule o emprego de fios transfixantes, principalmente quando estes fios são deslocados como é o caso do transporte femoral. Entretanto, nos nossos pacientes submetidos ao transporte femoral, não observamos as complicações clínicas causadas pela colocação imprópria dos pinos ou fios, como as lesões dos nervos, dos vasos, sindromes de compartimento ou outras previamente mencionadas por Behrens(1989)1. Mercadante $(1997)^{10}$ e Mercadante e Santin(1997) ${ }^{11}$ obtiveram 95\% de resultados satisfatórios em 18 pacientes submetidos ao transporte ósseo da perna. Consideram o transporte ósseo um método revolucionário por possibilitar a indução da neogênese tecidual e consequentemente permitir o tratamento das grandes falhas ósseas. Avaliaram seus resultados pelos parâmetros propostos por Paley et al.(1989) ${ }^{12}$, tal qual em todas as publicações encontradas em extensa revisão bibliográfica (Mercadante, 1997) ${ }^{10}$. No entanto, consideram que uma nova sistemática de avaliação deveria ser instituída, por considerarem a avaliação dos resultados baseada nos parâmetros propostos por Paley et al.(1989) ${ }^{12}$ complacente e tolerante, com o que concordamos plenamente.

\section{CONCLUSÕES}

Nossos resultados indicam que a resposta biológica ao transporte ósseo é formidável, com a formação do regenerado reparando grandes falhas ósseas. No entanto, achamos que o aparelho circular externo preconizado por llizarov, principalmente pelo fato de utilizar fios transfixantes, não pode ser considerado a forma ideal para realização do tratamento proposto, uma vez que traz consigo muitas complicações e sofrimento para os pacientes.

\section{CONCLUSIONS}

Our results indicate that the biological response to bone transport is formidable, with the formation of a regenerate which repairs big bone fissures. However, we think that the external circular apparatus recommended by llizarov, mainly because it uses transfixant wires, cannot be considered the ideal form to perform the proposed treatment, since it causes the patients several complications and suffering.

\section{REFERÊNCIAS}

1. BEHRENS, F.: General theory and principles of external fixation. Clin. Orthop. 241: 15-23, 1989.

2. CATAGNI, M. A.; FELICI, J.V.N.: Alongamento de dois níveis e o método de llizarov (trifocal) no tratamento da pseudoartrose tibial com perda óssea. Rev. Bras. Ortop. 31: 613-619, 1996.

3. GREEN, S.A.: Skeletal defects. A comparison of bone grafting and bone transport for segmental skeletal defects. Clin. Orthop. 301: 111-117, 1994.

4. GUSTILO, R. B.; MENDOZA, R.M.; WILLIANS, D.N.: Problems in the management of type III (severe) open fractures: a new classification of type III open fractures. J. Trauma 24: 742-746, 1984.

5. ILIZAROV, G. A.: The tension-stress effect on the genesis and growth of tissues: Part I. The influence of stability of fixation and soft-tissue preservation. Clin. Orthop. 238: 249-281, 1989.

6. ILIZAROV, G. A.: The tension-stress effect on the genesis and growth of tissues: Part II. The influence of the rate and frequency of distraction. Clin. Orthop. 239:263-285, 1989.

7. ILIZAROV, G. A.: Clinical application of the tension-stress effect for limb lengthening. Clin. Orthop. 250: 8-26, 1990.

8. ILIZAROV, G. A.; LEDYAEV, V. I.: The replacement of long tubular bone defectes by lengthening distraction osteotomy of one of the fragments. Clin. Orthop. 280: 7-10, 1992.

9. LEIVAS, T.P.; LEOPIZZI, N; CASSEL, A.P.; SOUZA, A.S.; OLIVEIRA, M.A.; CATENA, R.S.; TARGA, W.H.C.: Determinação da capacidade de retenção dos parafusos fixadores e tensores dos fixadores externos circulares de llizarov. Rev. Bras. Ortop. 31: 638-642, 1996.

10. MERCADANTE, M.T.: Tratamento da pseudoartrose da tíbia com falha óssea pelo método de llizarov. Tese Doutoramento - Faculdade Ciências Médicas Santa Casa São Paulo - São Paulo, 1997.

11. MERCADANTE, M.T.; SANTIN, R.L.: Tratamento da pseudoartrose da tíbia com falha óssea pelo método de llizarov. Rev. Bras. Ortop., 32: 591-599, 1997.

12. PALEY, D.: CATAGNI, M. A.; ARGNANI, F.; VILLA, A.; BENEDETTI, G. B.; CATTANEO, R.: llizarov treatment of tibial nonunion with bone loss. Clin. Orthop. 241: 146-165, 1989.

13. SCHWARTSMAN, V; CHOI, S.H.; SCHWARTSMAN, R.: Tibial nonunion. Treatment tactics with the llizarov method. Orthop. Clin. of North Am. 31:639 653, 1990. 